\title{
Le fortificazioni di Piombino di Leonardo da Vinci: la riscoperta delle tracce dell'impianto rinascimentale attraverso il rilievo digitale e il disegno
}

\author{
Stefano Bertocci \\ Matteo Bigongiari
}

Abstract

II contributo presenta le linee generali della ricerca, ancora in corso, sulla attività di Leonardo come architetto militare a Piombino in Toscana, nei primissimi anni del Cinquecento, alle dipendenze prima del Valentino e poi della Repubblica di Firenze. Attraverso lo studio della documentazione storica relativa allo sviluppo della cittadina toscana e il rilievo scientifico delle strutture fortificate che ancora permangono, seppure in parte manomesse e mutilate, si è tentato di dare un fondamento scientifico all'analisi dei numerosi disegni di Leonardo che ci sono pervenuti principalmente attraverso la raccolta del Codice II della Biblioteca Nazionale di Madrid.

Questa ricerca si fonda sull'ipotesi di utilizzo delle moderne tecnologie di rilievo digitale per cercare di riconoscere, unitamente alle analisi condotte sulle fonti storico documentarie e attraverso le scarse ma affidabili analisi archeologiche e all'analisi delle stratigrafie che le superfici murarie superstiti presentano, le porzioni che sopravvivono attualmente di quello che poteva essere il sistema fortificato della cittadina nel primo Cinquecento. Questi risultati sono stati infine confrontati con i disegni di Leonardo da Vinci che illustrano i rilievi e i progetti per le difese della Signoria di Piombino ottenendo un certo numero di interessanti riscontri.

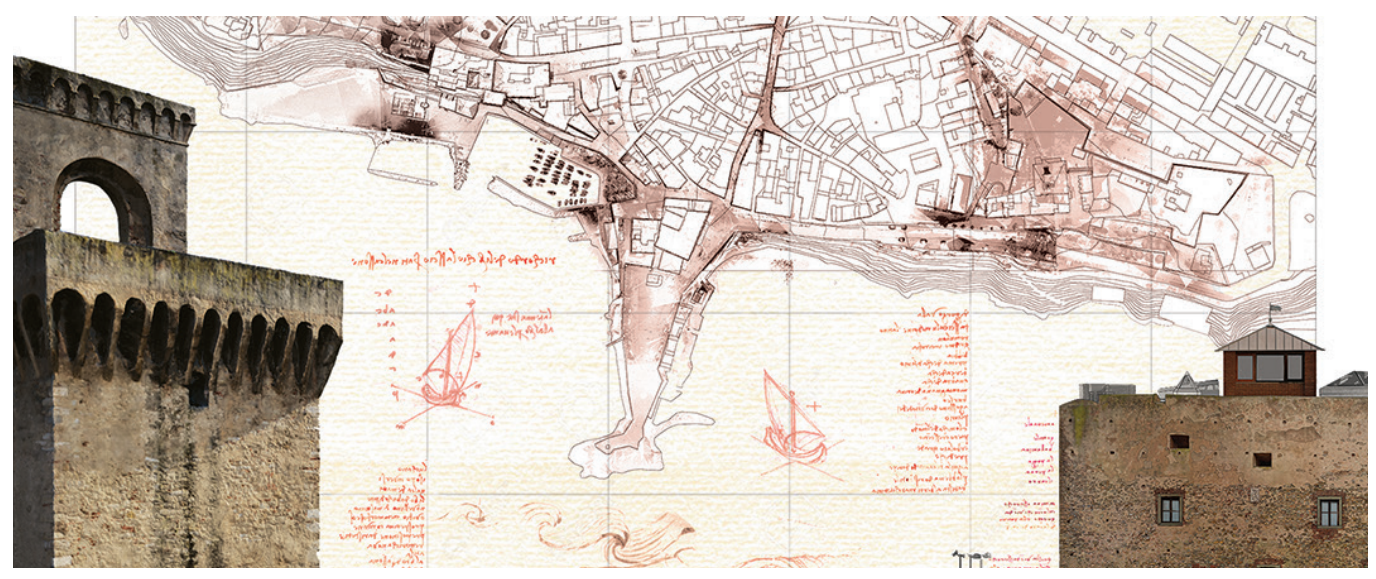




\section{Le motivazioni della ricerca e un nuovo modo confrontarsi con i taccuini del maestro}

II presente lavoro intende dare un approfondimento sull'attività di Leonardo come architetto militare a Piombino in Toscana, nei primissimi anni del Cinquecento, alle dipendenze prima del Valentino e poi della Repubblica di Firenze. Attraverso lo studio della documentazione storica relativa allo sviluppo della cittadina toscana e il rilievo scientifico delle strutture fortificate che ancora permangono, seppure in parte manomesse e mutilate, si è tentato di dare un fondamento scientifico basato sulle risultanze del rilievo digitale e della documentazione storica all'analisi dei numerosi disegni di Leonardo che ci sono pervenuti principalmente attraverso la raccolta del Codice II della Biblioteca Nazionale di Madrid. I disegni e gli scritti di Leonardo, e non solo quelli inerenti al tema di Piombino, sono stati già approfonditamente analizzati secondo molti aspetti differenti: sotto il profilo storico, tentando di ricostruire la sequenza temporale degli eventi e dei documenti legati alla figura di Leonardo; sotto quello storico-artistico, ricercando le caratteristiche espressive del disegno di Leonardo e inserendole all'interno del panorama culturale proprio del Rinascimento; dal punto di vista del ductus, il cambiamento della scrittura e dei segni con la maturazione del maestro. Il presente lavoro, tenendo presenti tutte le analisi e interpretazioni precedentemente condotte dagli esperti del settore, si basa in prima battuta sulla lettura sinottica delle fonti, concentrandosi nello specifico sull'analisi dei disegni e dei progetti per Piombino contenuti nel Codice II conservato alla Biblioteca Nazionale di Madrid.

In particolare, è stato anche molto utile, ai fini dell'interpretazione dei disegni, l'interpretazione dei testi, che erano stati annotati da Leonardo da Vinci ai margini delle illustrazioni, oppure anche sopra gli schizzi stessi, quando, probabilmente nella fretta del sopralluogo preliminare, il maestro riutilizzava gli spazi dei fogli che poi sono stati successivamente rilegati in quaderni di appunti [I].

Questa ricerca si fonda sull'ipotesi di utilizzo delle moderne tecnologie di rilievo digitale per cercare di riconoscere, unitamente alle analisi condotte sulle fonti storico-documentarie e attraverso le scarse ma affidabili analisi archeologiche e all'analisi delle stratigrafie che le superfici murarie superstiti presentano, le porzioni che sopravvivono attualmente di quello che poteva essere il sistema fortificato della cittadina nel primo Cinquecento. Questi risultati sono stati infine confrontati con i disegni di Leonardo da Vinci che illustrano i rilievi e i progetti per le difese della Signoria di Piombino ottenendo un certo numero di interessanti riscontri e i cui primissimi risultati sono stati presentati nel convegno Fortmed 2020 [2].

Gli studi relativi all'intervento leonardesco a Piombino hanno una vita relativamente breve, prevalentemente dovuti alla recente scoperta, negli anni ' 60 del secolo scorso, dei due codici madrileni che raccolgono le attività del maestro nella Signoria degli Appiani; nonostante che gli storici siano concordi sull'attribuire a Leonardo un periodo di permanenza a Piombino, nelle ricerche il tema delle fortificazioni progettate per Jacopo IV Appiani è sempre stato affrontato in modo sommario, senza tentare di ricondurre ad architetture specifiche delle fortificazioni della città i disegni leonardeschi, fino a che 20 anni fa la ricerca di Amelio Fara ha consentito di restituire all'intervento di Leonardo un doveroso approfondimento [3].
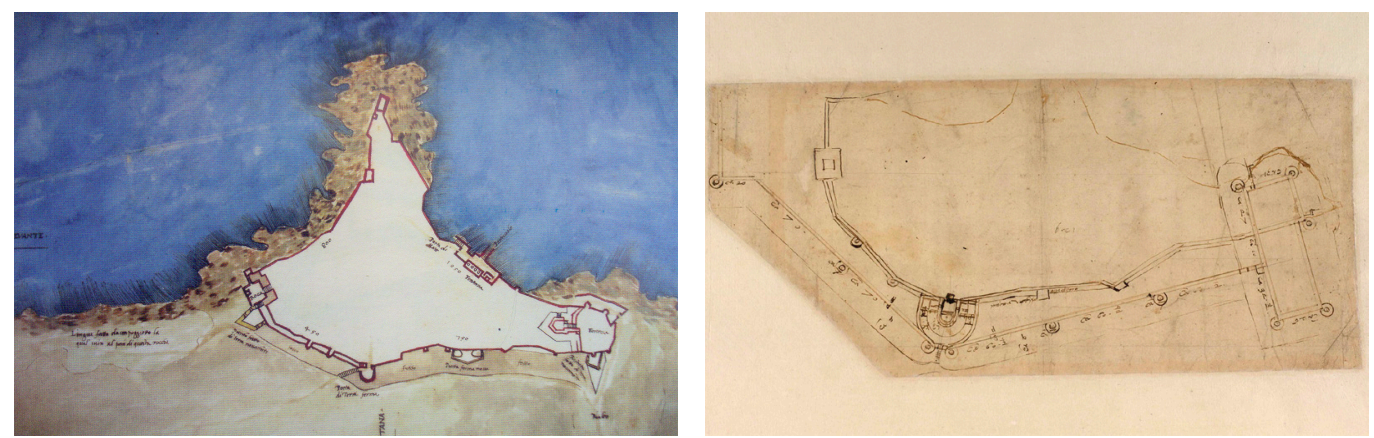
I disegni che ci sono pervenuti nascono come schizzi di studio, come disegni preparatori per presentare un progetto ben più dettagliato di cui si sono perse le tracce: il taccuino in cui sono conservati, il Codice II custodito alla Biblioteca Nazionale di Madrid, veniva utilizzato dal maestro come un quaderno di appunti su cui annotava, come era solito fare, gli argomenti più svariati che gli erano utili sul momento; è perciò frequente, quasi in tutte le pagine del manoscritto, trovare testi e disegni riguardanti tematiche molto differenti tra loro, che spesso si sovrappongono come un palinsesto che rende a volte difficilmente comprensibile la prima intenzione leonardiana nell'utilizzo dei fogli [4]. Quello che ancora era necessario sviluppare nella ricerca sull'intervento di Leonardo era uno sguardo ai suoi disegni dal punto di vista architettonico, cercando di comprendere non solo la morfologia degli edifici e delle planimetrie rappresentate, ma anche il metodo con cui l'artista si approcciava alla progettazione di architetture fortificate e le caratteristiche della sua rappresentazione architettonica, sia dal punto di vista artistico che tecnico.

Tutto questo ha portato a riesaminare i documenti originali andando ad analizzare i palinsesti che si possono riscontrare nei vari fogli del codice madrileno che in seguito a una attenta analisi restituiscono una vera e propria stratigrafia delle fasi di lavoro affrontate da Leonardo nell'approccio alla progettazione delle fortificazioni di Piombino.
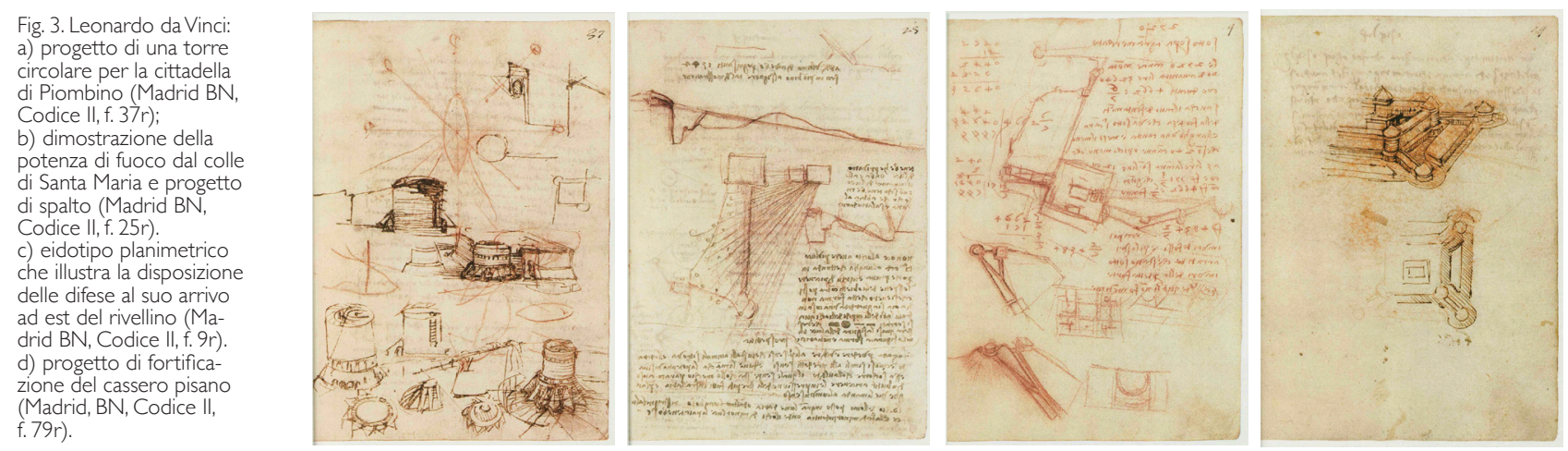

\section{Il contributo del rilievo scientifico alla analisi critica dei taccuini}

La ricerca qua presentata si sviluppa su due metodologie di ricerca differenti: una di studio delle fonti, per comprendere a fondo gli studi e le problematiche che riguardano vari argomenti a carattere storico, architettonico ed evolutivo; un'altra di lavoro pratico sul campo che riguarda lo svolgimento del rilievo, a diretto contatto con le architetture di Piombino.

Per questo motivo è stata divisa in più parti: una prima in cui lo studio delle fonti è utile a estrarre le informazioni riguardanti le conoscenze tecniche, architettoniche e militari, di Leonardo da Vinci, oltre che l'evoluzione delle fortificazioni alla fine del Quattrocento che tanto hanno influenzato la progettazione militare; una seconda parte si focalizza sul caso studio di Piombino, descrivendone sia le vicende evolutive delle sue fortificazioni fino all'arrivo di Leonardo, sia i disegni leonardiani e i progetti piombinesi sia lo sviluppo dei rilievi digitali delle fortezze eseguiti in situ [5].

Lo studio e la sintesi delle esperienze di Leonardo da Vinci in ambito architettonico sono stati prettamente funzionali a comprendere le conoscenze tecniche del maestro e il loro sviluppo nel tempo: mentre più comunemente si conoscono le doti artistiche e l'inventiva in ambito tecnico-scientifico di Leonardo, di cui sono estremamente note e trattate le opere d'arte e gli studi di macchine e di meccanica, altrettanto non si può dire degli impegni e dei progetti che sono stati eseguiti in ambito architettonico; è stato possibile delineare le conoscenze e gli interessi di architettura che avevano influenzato sia Leonardo che gli altri artisti delle corti rinascimentali, i quali sicuramente si scambiavano, opinioni confrontandosi sulle relative esperienze. 
Appurato che le esperienze di Leonardo di architettura sono poco conosciute, probabilmente soprattutto a causa della scarsità di edifici effettivamente realizzati e delle scarse testimonianze materiali a oggi rinvenute delle opere da lui progettate, è necessario considerare che il caso studio oggetto della ricerca riguarda un ambito degli studi del maestro ancor meno noto: si tratta degli studi di fortificazioni, dei quali Leonardo, proveniente dalla cultura delle botteghe artistiche fiorentine, in un primo periodo non era assolutamente esperto. Pertanto è stato necessario estendere il lavoro confrontandosi con l'evoluzione delle teorie e della pratica del sapere architettonico-militare per arrivare a comprendere alcune delle idee di Leonardo in questo settore e a inserire il lavoro dell'artista dentro un ben più ampio scenario storico: per l'evoluzione delle fortificazioni a partire della seconda metà del Quattrocento inizia un cambiamento fondamentale di tecniche ossidionali e difensive, spinto in Italia dalla critica situazione politica e militare, in cui Leonardo si trova a operare. II lavoro di Leonardo si inquadra dunque come contributo teorico pratico relativo alla necessaria evoluzione morfologica delle strutture difensive a partire, ad esempio, dalle prime fortificazioni che presentavano torrioni poligonali con l'intento di fancheggiare le cortine, nei domini dei Malatesta e dei Montefeltro. Fondamentale importanza per il maestro ebbe lo studio di Francesco di Giorgio Martini, una delle prime versioni del suo trattato di architettura fu sicuramente in possesso di Leonardo influenzandone le teorie architettoniche e militari, e lo stile più maturo, o meglio più in linea con le esigenze del primo Cinquecento di una difesa sistematica, come negli esperimenti di Antonio da Sangallo all'interno dei possedimenti pontifici dell'Italia Centrale [6].

La ricerca sulla città di Piombino ha comportato inoltre la ricostruzione dalle fonti documentarie e bibliografiche cercando di ricucire, non sempre facilmente, le interpretazioni delle fonti e dei vari autori sull'evoluzione del suo circuito fortificato della città. Questo lavoro si è reso necessario per interpretare il rilievo delle strutture attualmente esistenti che logicamente riportano tracce che partono dalla nascita del castello del XI secolo, all'ampliamento medievale con i successivi interventi, per riuscire a delineare un quadro sufficientemente chiaro della situazione precedente all'arrivo di Leonardo da Vinci. Lo studio della documentazione storica è stato integrato dalle recenti analisi archeologiche su alcune strutture della città che hanno permesso di incrementare la conoscenza delle fortificazioni piombinesi [7]. Per interpretare correttamente i disegni del maestro, le interpretazioni dello stato di fatto, i rilievi, così come le proposte progettuali, la maggior parte dei quali raccolti nel Codice II di Madrid, e gli argomenti trattati nei testi che li accompagnano è stato di fondamentale importanza ricostruire lo scenario nel quale Leonardo si trovò a operare.

II rilievo digitale della città fortificata di Piombino è stato quindi uno dei pilastri della ricerca. I rilievi, realizzati con le contemporanee tecnologie digitali, laser scanner e SfM, hanno resti-

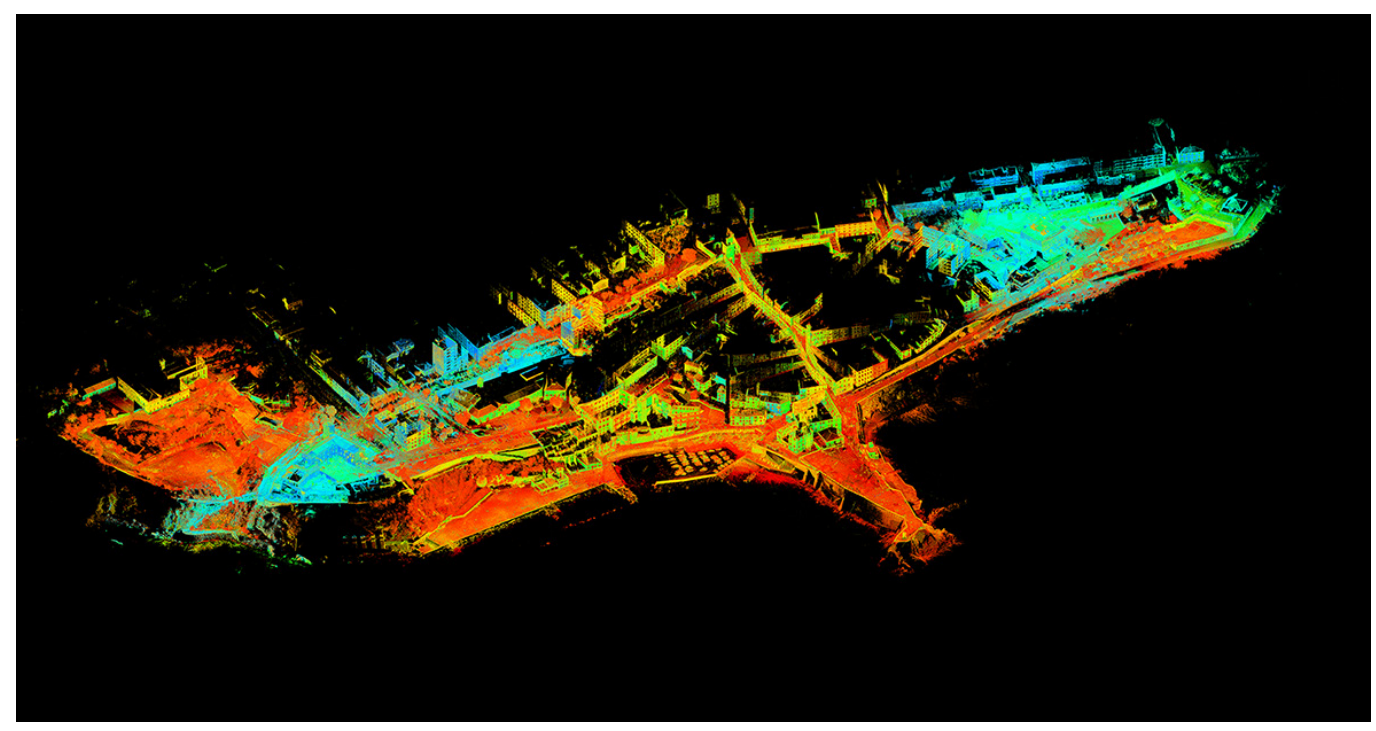




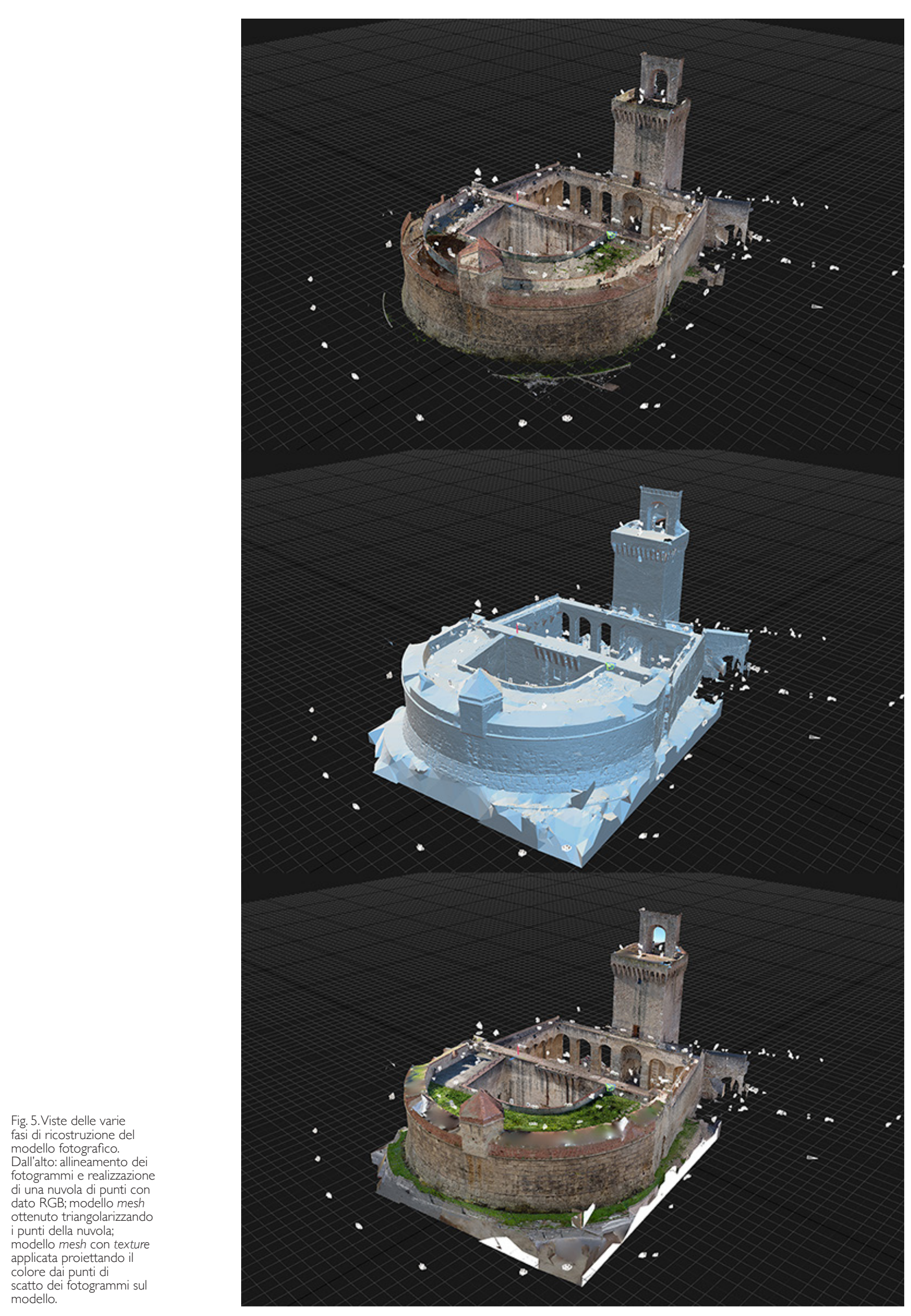


Fig. 6. Prospetto della cittadella di Piombino con sovrapposizione
della nuvola di punti lase scanner: sono in evidenza le torri e le mura quattrocentesche.

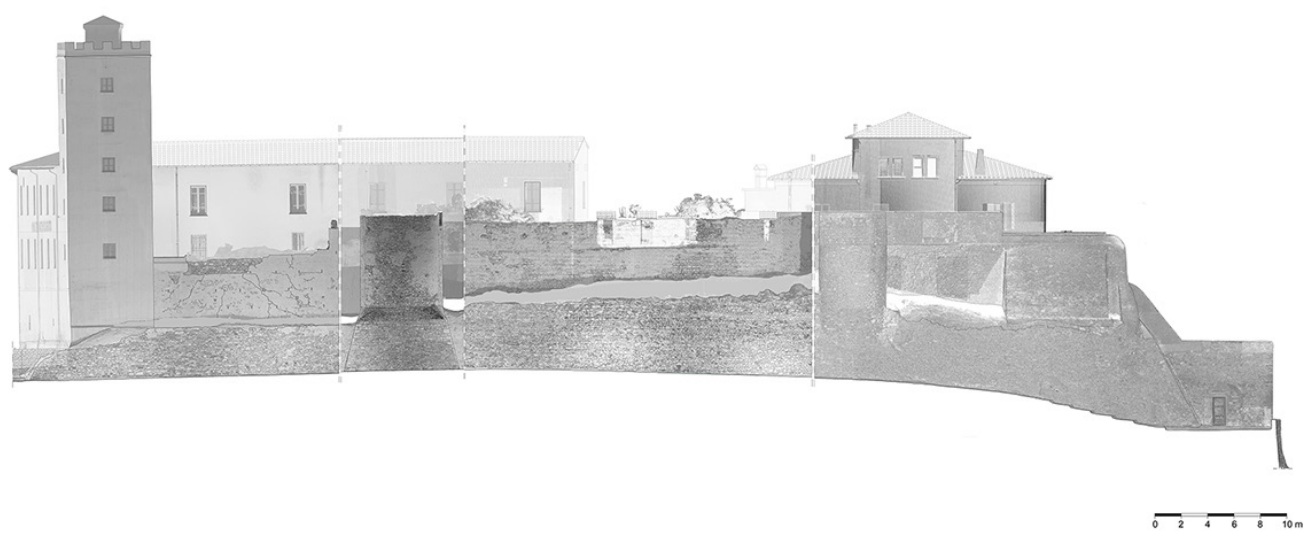

tuito lo stato dei fatto delle architetture difensive della città e i risultati sono stati sintetizzate in una serie di restituzioni alla scala architettonica, raccolti in un atlante di elaborati grafici, che descrivono la morfologia delle fortificazioni, la consistenza e lo sviluppo dei singoli apparati difensivi suddivisi per tipologie, arricchiti da accurate descrizioni delle superfici e dei materiali utili alle successive interpretazioni relative alle tecniche costruttive e alle tecnologie impiegate, oltre a costituire un interessante contributo alla lettura della stratigrafia degli elevati di ogni singola struttura [8].

Il confronto infine con i disegni del corpus leonardiano è stato realizzato attraverso delle 'schede di allineamento' nelle quali sono state prese in considerazione le stesse situazioni considerate da Leonardo, i punti nodali del sistema difensivo quali il Castello, la Fortezza, il Rivellino. Una volta scelti gli elaborati di interesse che potevano essere paragonati, piante e sezioni, sono stati riportati alla scala del rilievo i disegni del maestro relativi a quegli stessi oggetto, senza alcuna modificazione delle proporzioni, e quindi sono stati allineati agli elaborati grafici del rilievo digitale realizzato. I risultati in alcuni casi sono stati sorprendenti, soprattutto per quanto riguarda l'affidabilità dei rilievi realizzati da Leonardo, come nel caso del perimetro della cortina della Fortezza, oppure nel confronto fra la sezione di progetto della cortina della fortezza stessa con lo stato attuale della cortina e del fossato. Come appare dagli elaborati proposti il rilievo è stato quindi lo strumento fondamentale per comprendere le caratteristiche degli edifici che Leonardo vide nel Cinquecento e che ha adattato e modificato con il suo intervento. La lettura critica degli elaborati di rilievo ha anche permesso di documentare molte parti che nel corso del tempo hanno subito profonde mutazioni e che non permettono, se non all'occhio esperto, di rintracciare le porzioni più antiche dei fabbricati. Sulla base di promettenti risultati ottenuti stiamo procedendo alla lettura critica di tutto il corpus documentario realizzato per ottenere un quadro completo, scientificamente convincente e assolutamente nuovo, delle strutture delle fortificazioni della città che potrebbero riferirsi all'intervento di Leonardo.

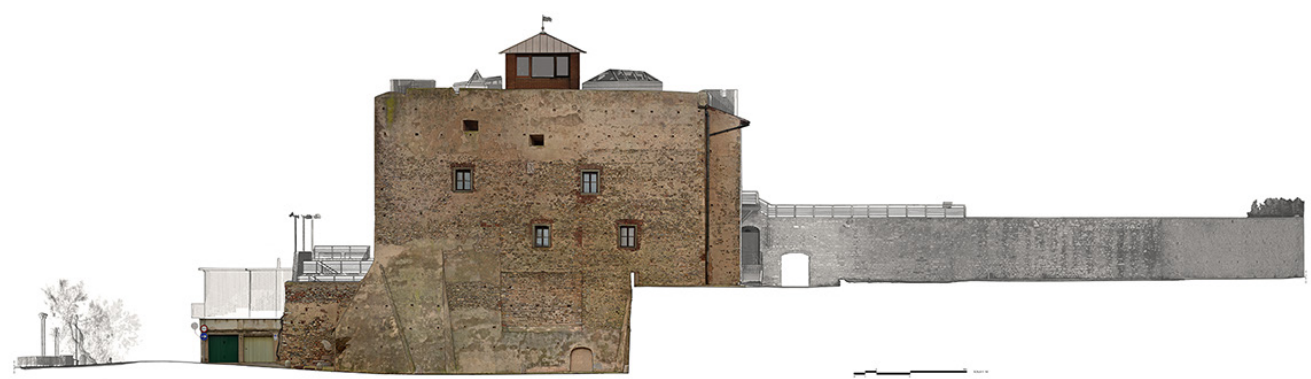


Fig. 8. Immagine della nuvola di punti dove sono evidenziate in rosso

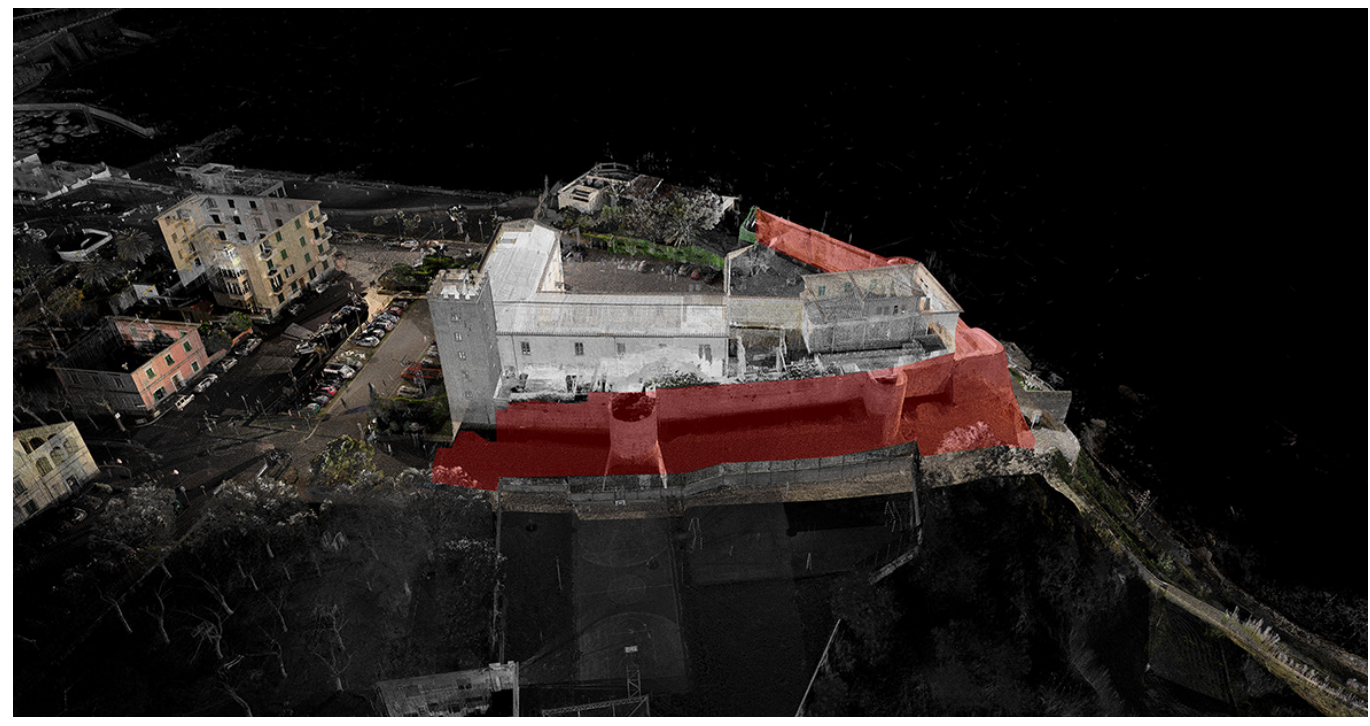

\section{Conclusioni}

La ricerca mostrata ha potuto verificare l'importanza dell'utilizzo del rilievo digitale come fondamentale strumento di conoscenza delle architetture; grazie al suo utilizzo è stato possibile realizzare un impianto metodologico per comprendere a fondo non solo le intenzioni progettuali di Leonardo da Vinci a Piombino ma anche per riconoscere ed evidenziare la collocazione in planimetria di altri disegni dell'artista legati alla città toscana. La realizzazione di un dettagliato database morfologico che descrive le architetture fortificate era assente, e sarà adesso utile a sviluppare ulteriori studi legati all'architettura militare di Piombino. La ricerca riguardante l'intervento di Leonardo da Vinci potrà essere approfondita ricostruendo per tutte le architetture rilevate, laddove è ancora possibile, una attenta analisi delle stratigrafie murarie, documentare scientificamente l'evoluzione di queste strutture anche in relazione alle fonti storico-documentarie. II caso studio di Piombino, oltre a permettere di approfondire l'intervento del maestro, ha potuto evidenziare, per via della grande quantità di disegni preparatori riconosciuti, il metodo progettuale e l'approccio, molto pratico di Leonardo all'architettura e al progetto.

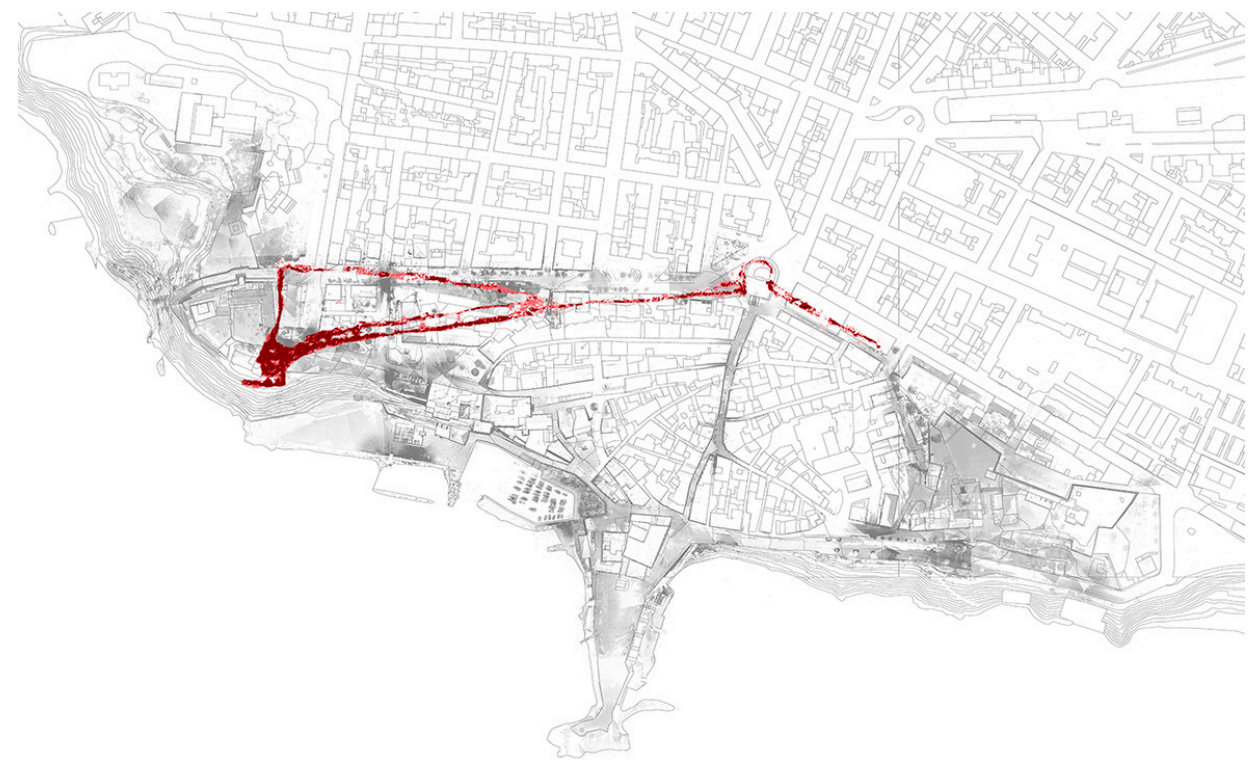

Fig. 9. Sovrapposizione tra rilievo urbano e schizzo di progetto per la torre della cittadella e al connessione con il Rivellino della Porta di Terra. 


\section{Note}

[I] I disegni di Leonardo da Vinci su Piombino sono stati analizzati da Fara [Fara 1999] e recentemente approfonditi da Bigongiari [Bigongiari 2020] nella sua tesi di dottorato in architettura.

[2] Per un primo contributo sui risultati dei rilievi vedi: Bertocci, Bigongiari 2020.

[3] Le prime analisi sommarie dei disegni leonardiani di Piombino sono state fatte da Heidenreich [Heidenreich 1974].

[4] II Codice II di Madrid è stato studiato e trascritto da Reti [Reti 1974].

[5] Gli studi di architettura civile e militare su Leonardo da Vinci hanno come principali riferimenti Pedretti [Pedretti 1978] e Marani [Marani 1984].

[6] Per approfondire lo sviluppo dell'architettura militare moderna alla fine del Quattrocento vedi Fiore [Fiore 2019].

[7] Per uno studio approfondito delle fonti storiche sulla città di Piombino vedi: Ceccarelli Lemut 2003; Bianchi 2006; Lazzarini 2011 .

[8] Le fasi di rilievo hanno previsto di completare l'acquisizione dati sia delle fortificazioni che di tutto il percorso che era occupato dalla cinta muraria, e sono state eseguite con strumentazioni laser scanner: per il disegno e la restituzione delle superfici materiche delle architetture sono state mappate fotograficamente tutte le superfici delle architetture esistenti, per un approfondimento vedi: Bertocci, Bigongiari 2020; Bigongiari 2020.

\section{Riferimenti bibliografici}

Bertocci Stefano, Bigongiari Matteo (2020). Rilievo digitale delle fortificazioni di Piombino. In Navarro Palazón, García-Pulido (a cura di). FORTMED2020. Congresos de la Universitat Politècnica de València, Defensive Architecture of the Mediterranean. Granada, I-3 ottobre 2020, vol X, pp. 247-254.

Bianchi Giovanna (2006). Piombino. La chiesa di Sant'Antimo sopra i canali. Ceramiche e architetture per la lettura archeologica di un abitato medievale e del suo porto. Firenze: All'insegna del Giglio.

Bigongiari Matteo (2020). L'architettura fortificata di Leonardo da Vinci in Toscana. Rilievi digitali delle fortificazioni di Piombino per la interpretazione critica dei progetti leonardiani. Tesi di Dottorato di ricerca in Architettura, curriculum Rilievo e rappresentazione dell'architettura e dell'ambiente, Università degli Studi di Firenze. Tutor: prof. Stefano Bertocci, prof. Pilar Chìas Navarro.

Ceccarelli Lemut Maria Luisa (2003). Piombino. In Bianchi Giovanna (a cura di). Campiglia, un castello e il suo territorio. Firenze: All'insegna del Giglio, pp. 55-58.

Fara Amelio (1999). Leonardo a Piombino e l'idea della città moderna tra Quattro e Cinquecento. Firenze: Olschki Editore.

Fiore Francesco Paolo (2019). Architettura e arte militare, mura e bastioni nella cultura del Rinascimento. Roma: Campisano Editore.

Heydenreich Ludwig H. (1974). I progetti di Leonardo per fortificare Piombino. In Almanacco italiano, vol. LXXV, pp. $332-339$. Firenze: Giunti Editore.

Lazzarini Maria Teresa (201 I). Le chiese di Piombino. Pisa: Pacini Editore.

Marani Pietro C. ( 1984). L'architettura fortificata negli studi di Leonardo da Vinci. Firenze: Olschki Editore.

Pedretti Carlo (1978). Leonardo architetto. Milano: Electa.

Reti Ladislao (a cura di). (1974). Leonardo da Vinci. I Codici di Madrid. 5 voll. Firenze: Giunti Barbera.

\section{Autori}

Stefano Bertocci, Università di Firenze, stefano.bertocci@unifi.it

Matteo Bigongiari, Università di Firenze, matteo.bigongiari@unifi.it

Per citare questo capitolo: Bertocci Stefano, Bigongiari Matteo (2020). Le fortificazioni di Piombino di Leonardo da Vinci: la riscoperta delle tracce dell'impianto rinascimentale attraverso il rilievo digitale e il disegno/The fortifications of Piombino by Leonardo da Vinci: the discovery of the traces of the Renaissance system through digital survey and drawing. In Arena A., Arena M., Brandolino R.G., Colistra D., Ginex G., Mediati D., Nucifora S., Raffa P. (a cura di). Connettere. Un disegno per annodare e tessere. Atti del $42^{\circ}$ Convegno Internazionale dei Docenti delle Discipline della Rappresentazione/Connecting. Drawing for weaving relationships. Proceedings of the 42th International Conference of Representation Disciplines Teachers. Milano: FrancoAngeli, pp. 87-102. 


\title{
The Fortifications of Piombino by Leonardo da Vinci: the Discovery of the Traces of the Renaissance System through Digital Survey and Drawing
}

\author{
Stefano Bertocci \\ Matteo Bigongiari
}

Abstract

IThe paper presents the general lines of research, still in progress, on Leonardo's activity as a military architect in Piombino in Tuscany, in the early sixteenth century, employed first by Valentino and then by the Republic of Florence. Through the study of the historical documentation relating to the development of the Tuscan city and the scientific survey of the fortified structures that still remain, even if they are partially modified, an attempt was made to give a scientific foundation to the analysis of the numerous drawings by Leonardo that are mainly preserved in the collection of Code II of the National Library of Madrid.

This research is based on the hypothesis of using modern digital surveying technologies to try to recognize, together with the analyzes conducted on historical-documentary sources and through the reliable archaeological analyzes and the analysis of the stratigraphies that the wall surfaces present, the portions that currently survive of what could have been the fortified system of the town in the early sixteenth century. These results were finally compared with Leonardo da Vinci's drawings that illustrate the surveys and projects for the defenses of the Lordship of Piombino obtaining a number of interesting findings.

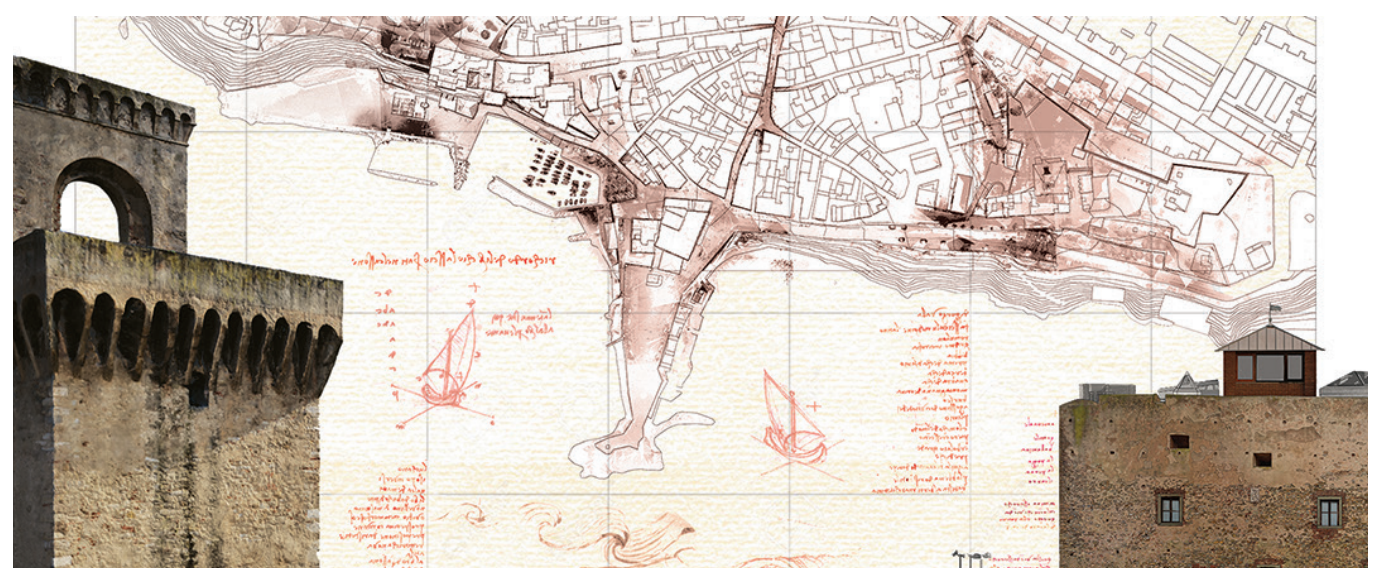




\section{The reasons for the research and a new way to deal with Leonardo's notebooks}

This work intends to give an in-depth look at Leonardo's activity as a military architect in Piombino in Tuscany, in the early sixteenth century, employed first by Valentino and then by the Republic of Florence. Through the study of the historical documentation relating to the development of the Tuscan city and the scientific survey of the fortified structures that still remain, even if they are partially modified, an attempt was made to give a scientific foundation to the analysis of the numerous drawings by Leonardo that are mainly preserved in the collection of Code II of the National Library of Madrid. Leonardo's drawings and writings, not only those relating to Piombino, have already been thoroughly analyzed according to many different aspects: from a historical point of view, trying to reconstruct the temporal sequence of events and documents related to the figure of Leonardo; from the historical-artistic one, researching the expressive characteristics of Leonardo's design and inserting them within the cultural context of the Renaissance; from the point of view of the ductus, the change in writing and signs with the maturation of the master. This work takes into account all the analyzes and interpretations, which were previously conducted by the experts of the various disciplines, and is based in the first instance on the synoptic reading of the sources, focusing specifically on the analysis of the drawings and projects for Piombino contained in the Code II of the National Library of Madrid.

In particular, it was also very useful for the interpretation of the drawings, the reading of the texts, which had been annotated by Leonardo da Vinci on the margins of the illustrations, or even above the sketches themselves: probably in the haste of the preliminary inspection, the master reused the spaces of the sheets which were subsequently bound in notebooks [I]. This research is based on the hypothesis of using modern digital surveying technologies to try to recognize, together with the analyzes conducted on historical-documentary sources and through the reliable archaeological analyzes and the analysis of the stratigraphies that the wall surfaces present, the portions that currently survive of what could have been the fortified system of the town in the early sixteenth century. These results were finally compared with Leonardo da Vinci's drawings that illustrate the surveys and projects for the defenses of the Lordship of Piombino, obtaining a number of interesting findings and the very first results of which were presented in the Fortmed 2020 conference [2].

The studies relating to Leonardo's intervention in Piombino have a relatively short life, mainly due to the recent discovery, in the 1960s, of the two Madrid codes that collect the master's activities in the Appiani dominion; although historians agree on attributing Leonardo a period of stay in Piombino, in research the theme of the fortifications designed for Jacopo IV Appiani has always been dealt with in a summary way, without attempting to trace the designs of the fortifications of the city to the specific architectures Leonardo, until 20 years ago the research of Amelio Fara allowed a due study [3].

The drawings we have received are born as sketches, as preparatory drawings to present a much more detailed project whose traces have been lost: the notebook in which they are kept, Code II of the National Library of Madrid, was used by the master as a notebook of

Fig. I. Giovanni Battista Fig. I. Giovanni Battista
Belluzzi, called Sanmarino, Fortifications of Piombino, Fortifications of Piombino,
1522 (BNF, National Fund, II. I.280, c.2 Ir).

Fig. 2. (Not by the hand of Leonardo da Vinci) project for a new fortified front for Piombino with relief of the fifteenth-century walls (Milan, Biblioteca Ambroisian Codex Atlanticus, f. I I5v).
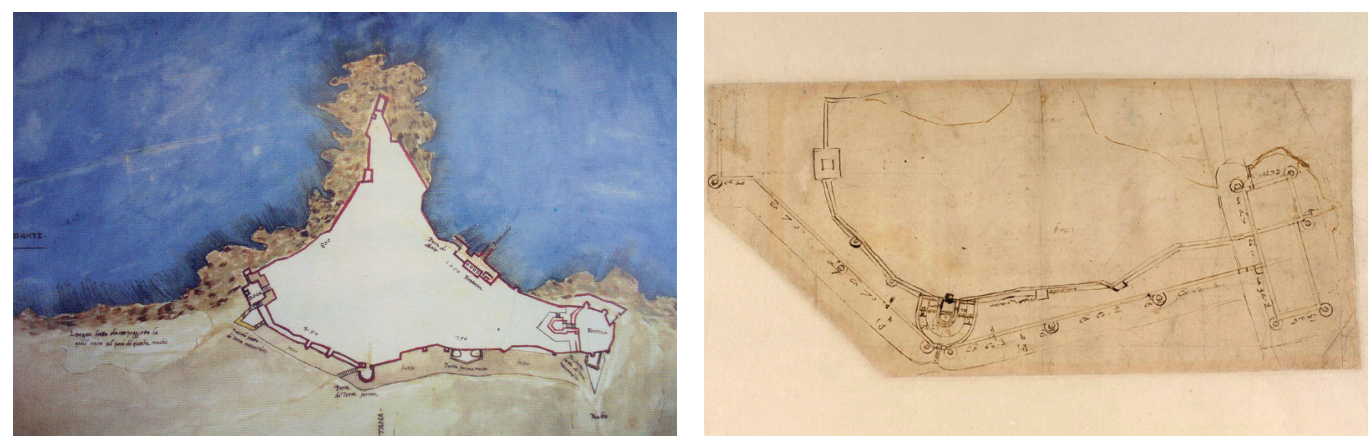
notes on which he wrote down, as he used to do, the most varied topics that were useful to him at the time; it is therefore frequent, almost in all the pages of the manuscript, to find texts and drawings concerning very different themes, which often overlap like a palimpsest which sometimes makes Leonardo's first intention in using the sheets difficult to understand [4]. What still needed to be developed in the research on Leonardo's intervention was a look at his drawings from an architectural point of view: it was attempted to understand not only the morphology of the buildings and the floor plans represented, but also the method by which the artist he approached the design of fortified architectures and the characteristics of his architectural representation, both from an artistic and technical point of view. All this has led to re-examine the original documents, analyzing the schedules that can be found in the various sheets of the Madrid code which, following careful analysis, provide a real stratigraphy of the work phases faced by Leonardo in the approach to design of the fortifications of Piombino.

Fig. 3. Leonardo da Vinci: a) project of a circular tower for the citadel of Piombino (Madrid NL, Code II, f. 37r):

b) demonstration

firepower from the hill of

Santa Maria and project Santa Maria and project of the battle (Madrid NL, Code Il, f. 25r);

c) eidotype planimetric

illustrating the disposition of the defenses on his

arrival east of the ravelin

(Madrid NL,Code II, f. 9r)

d) project for fortification of the Pisan cassero (Madrid NL, Code II, f. 79r).
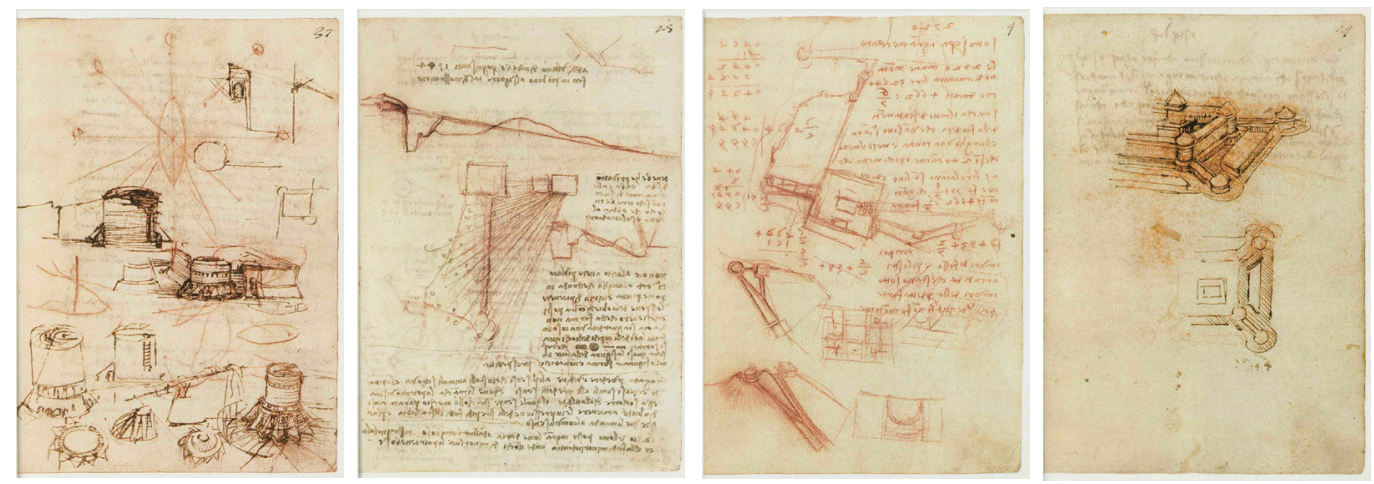

\section{The contribution of the scientific survey to the critical analysis of Leonardo's notebooks}

The research presented here is based on two different research methodologies: one for the study of sources, to fully understand the studies and problems that concern various historical, architectural and evolutionary topics; another of practical work in the field concerning the development of the survey, in direct contact with the architectures of Piombino.

For this reason, it has been divided into several parts: in a first one the study of the sources is useful for extracting information regarding Leonardo da Vinci's technical, architectural and military knowledge, as well as the evolution of the fortifications at the end of the fifteenth century which so much have influenced military design; a second part focuses on the case study of Piombino, describing both the evolutionary events of its fortifications up to the arrival of Leonardo, and the Leonardian designs and Piombino's projects as well as the development of digital surveys of the fortresses carried out in situ [5].

The study and synthesis of Leonardo da Vinci's architectural experiences were purely functional in understanding the master's technical knowledge and their development over time: while Leonardo's artistic skills and inventiveness are more commonly known (among them the works of art and the studies of machines and mechanics are extremely well known and treated), the same cannot be said of the commitments and projects that have been carried out in the architectural field; it was possible to delineate the knowledge and architectural interests that had influenced both Leonardo and the other artists of the Renaissance courts, who certainly exchanged opinions by comparing each other on the relative experiences. Having ascertained that Leonardo's experiences in architecture are little known, probably mainly due to the scarcity of buildings actually built and the scarce material evidence found to date of the works he designed, it is necessary to consider that the case study, object of the research, addresses a even less well-known area of the master's studies: these are the 
studies of fortifications, of which Leonardo, who came from the culture of the Florentine artistic workshops, was not an expert at first. Therefore it was necessary to extend the work by confronting the evolution of the theories and practice of architectural-military knowledge to get to understand some of Leonardo's ideas in this sector and to insert the artist's work into a much broader historical scenario: for the evolution of the fortifications starting from the second half of the fifteenth century, a fundamental change of obsessional and defensive techniques begins, driven in Italy by the critical political and military situation, in which Leonardo himself operates. Leonardo's work is therefore framed as a theoretical and practical contribution relating to the necessary morphological evolution of the defensive structures starting, for example, from the first fortifications that had polygonal towers with the aim of flanking the enceintes, in the domains of the Malatesta and Montefeltro. The study of Francesco di Giorgio Martini had fundamental importance for the master; one of the first versions of his architectural treatise was certainly in Leonardo's possession, influencing his architectural and military theories, and the more mature style: it was closer to the needs of the early sixteenth century for a systematic defense, as it can be seen from the work of Antonio da Sangallo within the pontifical possessions of Central Italy [6].

Research on the city of Piombino also involved reconstruction from documentary and bibliographic sources, trying to mend the interpretations of the sources and various authors on the evolution of its fortified circuit in the city. This work was necessary to interpret the survey of the currently existing structures that logically report traces that start from the birth of the I I th century castle, to the medieval expansion with subsequent interventions, to be able to outline a sufficiently clear picture of the situation prior to arrival by Leonardo da Vinci. The study of historical documentation has been integrated by recent archaeological analyzes of some structures of the city that have allowed to increase the knowledge of the Piombinesi fortifications [7].

To correctly interpret the master's drawings, the current state, the surveys, as well as the project proposals, most of which are collected in the Madrid II Code, and the topics written in the accompanying texts, it was of fundamental importance to reconstruct the scenario in which Leonardo was working.

The digital survey of the fortified city of Piombino was therefore one of the pillars of the research.The surveys, made with contemporary digital technologies, laser scanners and SfM, provided the state of the art of the city's defensive architectures and the results were summarized in a series of drawings at the architectural scale, collected in an atlas of elaborate graphics: these describe the morphology of the fortifications, the consistency and development of the individual defensive systems divided by typology, enriched by accurate descrip-

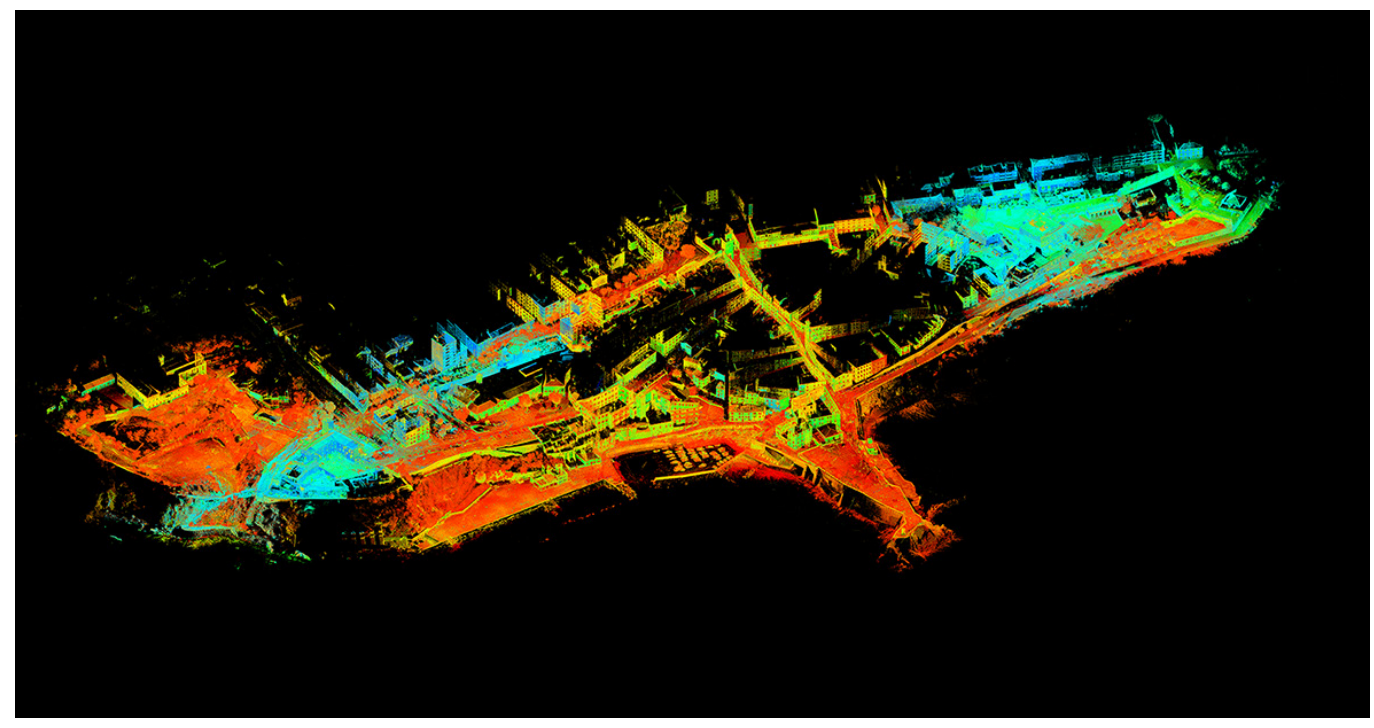




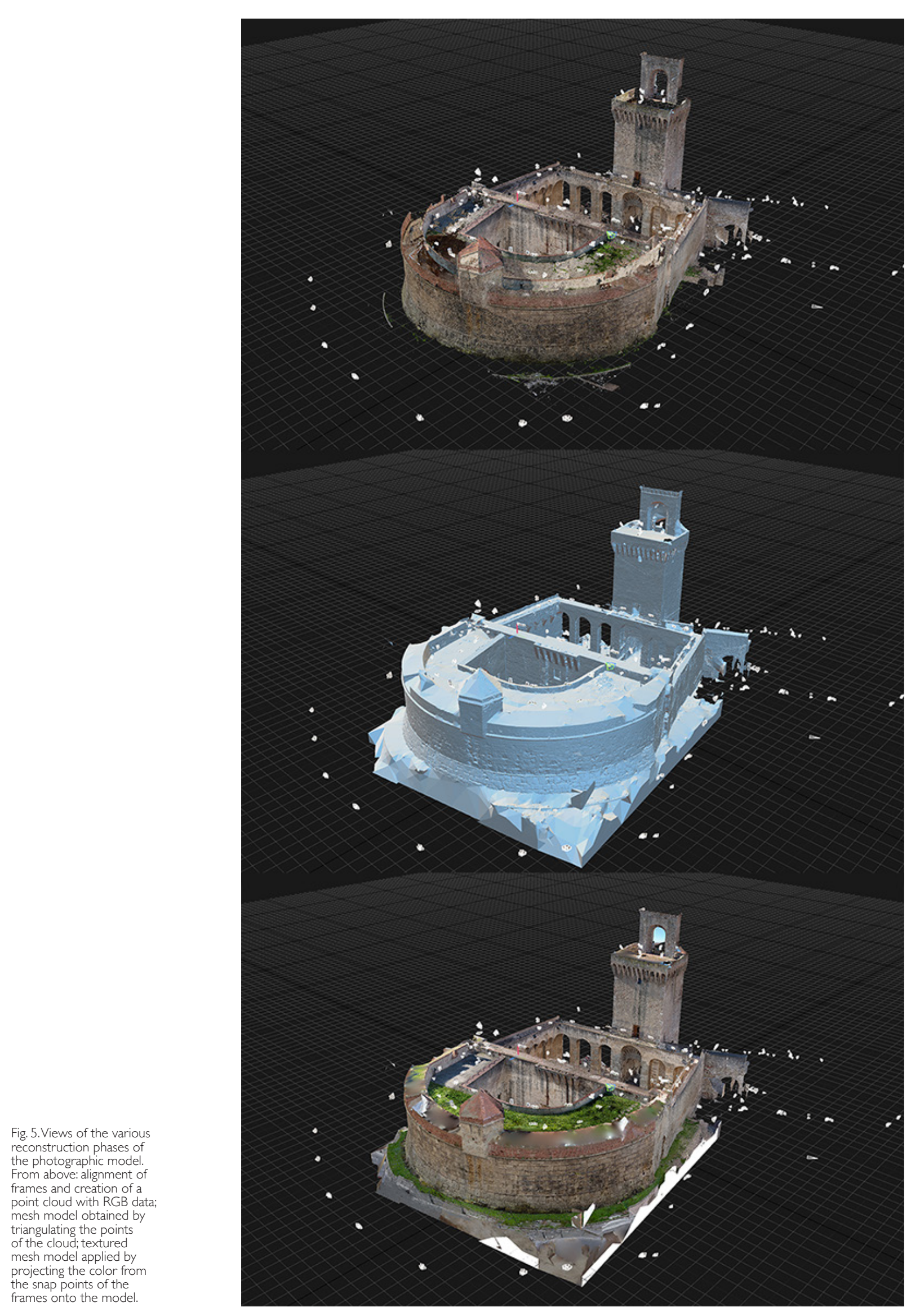


Fig. 6. Elevation of the citadel of Piombino with overlapping of the cloud of laser scanner points: the fifteenth-century towers and walls are highlighted.

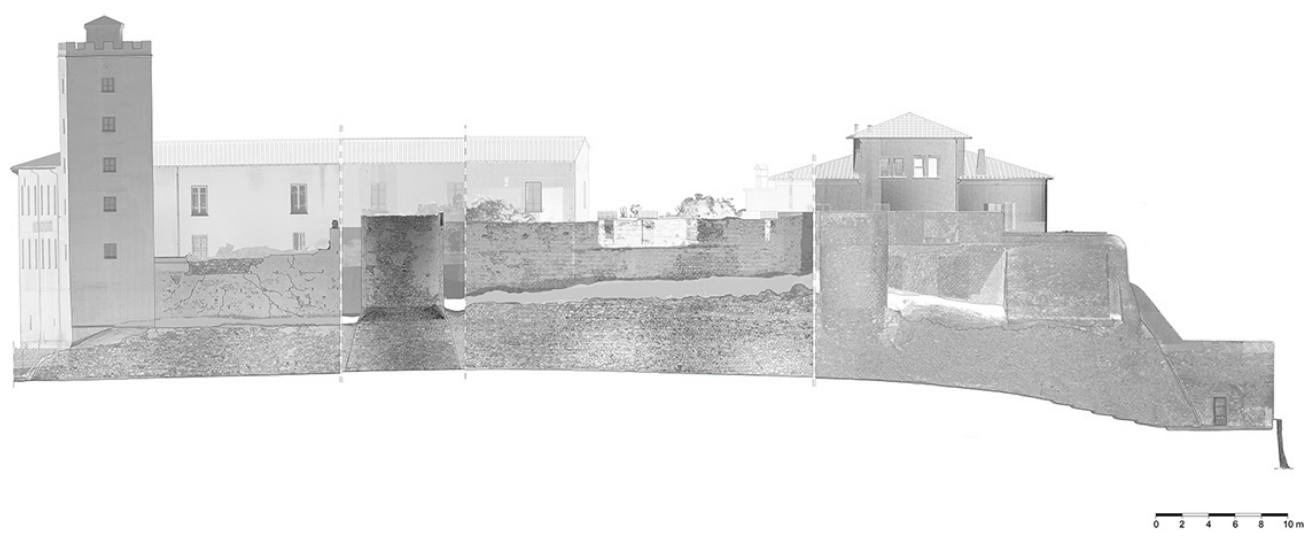

tions of the surfaces and materials, which are useful for subsequent interpretations relating to the construction techniques and technologies used, as well as constituting an interesting contribution to the reading of the stratigraphy of the elevations of each single structure [8]. Finally, the comparison with the drawings of the Leonardo body was made through 'alignment sheets', in which the same situations considered by Leonardo, the key points of the defensive system such as the Castle, the Fortress, the Rivellino were taken into consideration. Once the drawings of interest that could be compared were chosen, plans and sections, the Master's drawings relating to those same objects were brought back to the survey scale, without any change in the proportions, and then they were aligned to the drawings of the digital survey realized. The results in some cases have been surprising, especially as regards the reliability of the surveys carried out by Leonardo, as in the case of the perimeter of the enceinte of the fortress, or in the comparison between the design section of the enceinte of the fortress itself with the current state of the eincente and moat. As it appears from the proposed documents, the survey was therefore the fundamental tool to understand the characteristics of the buildings that Leonardo saw in the sixteenth century and which he adapted and modified with his intervention. The critical interpretation of the surveying documents has also allowed us to document many parts that have undergone profound changes over time and that do not allow, if not for the expert eye, to trace the oldest portions of the buildings. On the basis of promising results obtained, we are proceeding with a critical reading of the entire documentary corpus created to obtain a complete, scientifically convincing and absolutely new picture of the structures of the city's fortifications that could refer to Leonardo's intervention.

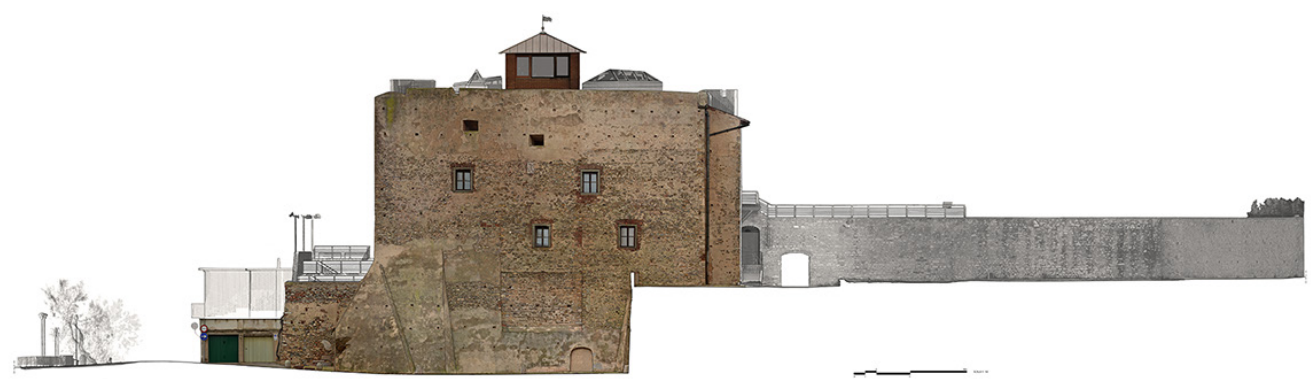


Fig. 8. Image of the cloud of points where structures dating back highlighted in red.

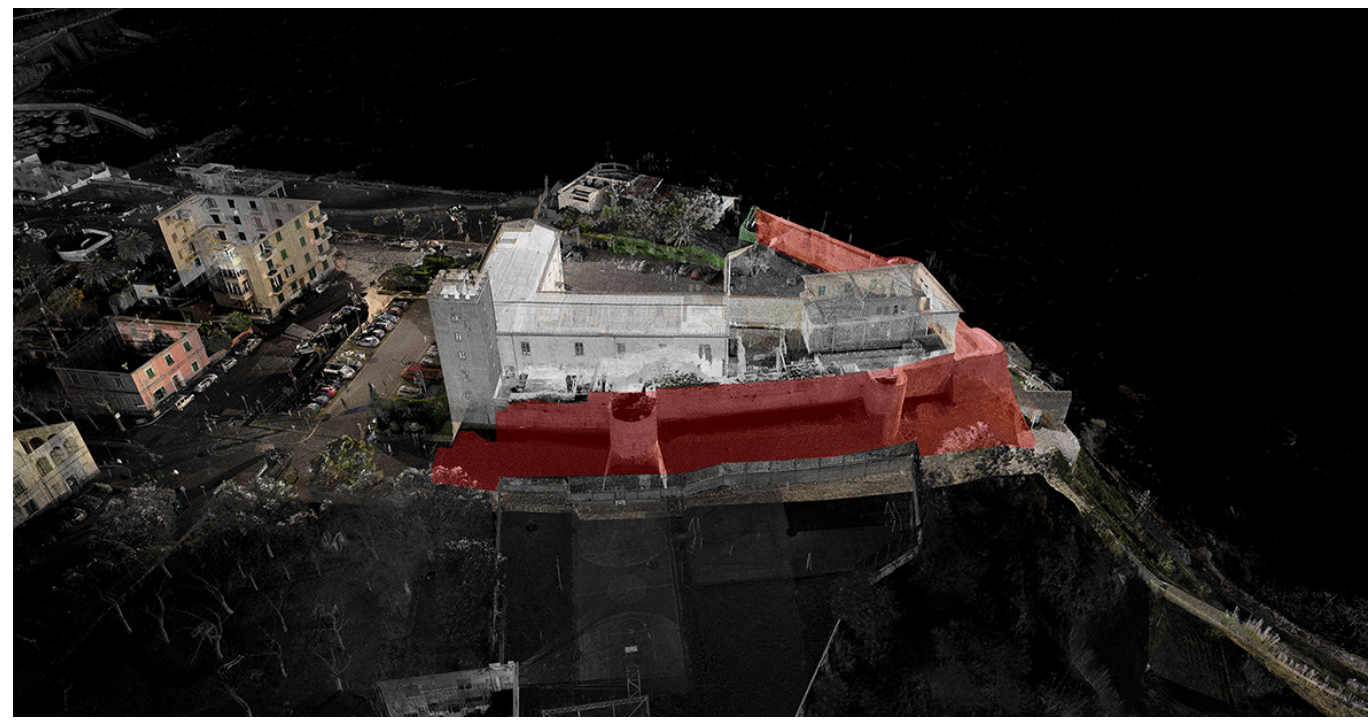

\section{Conclusions}

The research shown was able to verify the importance of using digital surveying as a fundamental tool for knowledge of architecture; thanks to its use, it was possible to create a methodological system to fully understand not only the design intentions of Leonardo da Vinci in Piombino but also to recognize and highlight the location on the plan of other Master's drawings related to the Tuscan city. The creation of a detailed morphological database describing the fortified architectures was absent, and will now be useful to develop further studies related to the military architecture of Piombino. The research concerning Leonardo da Vinci's intervention can be deepened by reconstructing a careful analysis of the building stratigraphies for all the architectures detected, where it is still possible, scientifically documenting the evolution of these structures also in relation to historical-documentary sources. The case study of Piombino, in addition to allowing to deepen the intervention of the Master, was able to highlight, due to the large amount of recognized preparatory drawings, the design method and Leonardo's very practical approach to architecture and design.

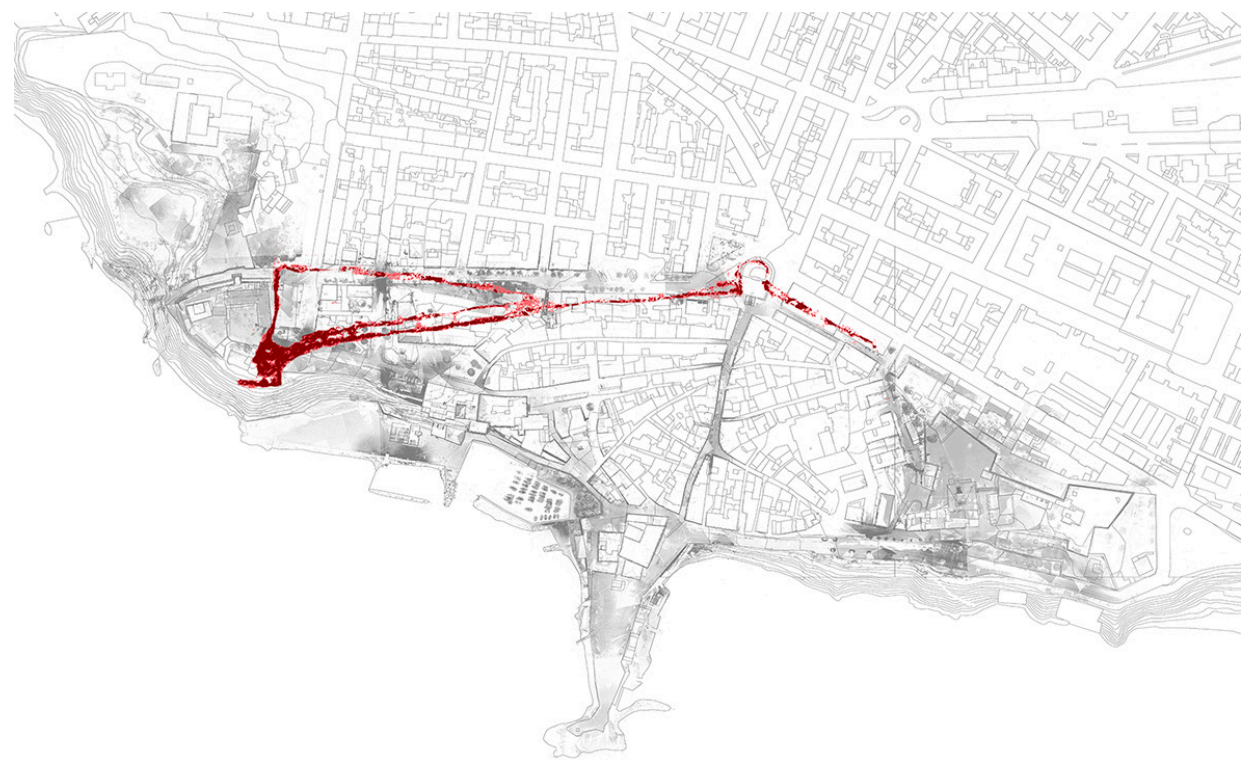

Fig. 9. Overlap between urban survey and project sketch for the citade tower and the conof the Porta diTerra. 


\section{Notes}

[I] Leonardo da Vinci's drawings on Piombino have been analyzed by Fara [Fara 1999] and recently studied in depth by Bigongiari [2020] in his doctoral thesis in architecture.

[2] For a first contribution on the results of the surveys see: Bertocci, Bigongiari 2020.

[3] The first summary analyzes of Piombino's Leonardo drawings were made by Heidenreich [Heidenreich 1974].

[4] The Madrid Code II was studied and transcribed by Reti [Reti 1974].

[5] The civil and military architecture studies on Leonardo da Vinci have as main references Pedretti [Pedretti 1978] and Marani [Marani 1984].

[6]To learn more about the development of modern military architecture at the end of the fifteenth century see Fiore [Fiore 2019].

[7] For a detailed study of the historical sources on the city of Piombino see Ceccarelli Lemut [2003], Bianchi [Bianchi 2006] and Lazzarini [Lazzarini 20l I].

[8] The survey phases involved completing the data acquisition both of the fortifications and of the entire path that was occupied by the walls, and were performed with laser scanner instruments: for the design and the restitution of the material surfaces of the architectures, they were mapped photographically all the surfaces of the existing architectures, for more information see: Bertocci Bigongiari 2020; Bigongiari 2020.

\section{References}

Bertocci Stefano, Bigongiari Matteo (2020). Rilievo digitale delle fortificazioni di Piombino. In Navarro Palazón, García-Pulido (eds.). FORTMED2020. Congresos de la Universitat Politècnica de València, Defensive Architecture of the Mediterranean. Granada, I-3 ottobre 2020, vol X, pp. 247-254.

Bianchi Giovanna (2006). Piombino. La chiesa di Sant'Antimo sopra i canali. Ceramiche e architetture per la lettura archeologica di un abitato medievale e del suo porto. Firenze: All'insegna del Giglio.

Bigongiari Matteo (2020). L'architettura fortificata di Leonardo da Vinci in Toscana. Rilievi digitali delle fortificazioni di Piombino per la interpretazione critica dei progetti leonardiani. Tesi di Dottorato di ricerca in Architettura, curriculum Rilievo e rappresentazione dell'architettura e dell'ambiente, Università degli Studi di Firenze. Tutor: prof. Stefano Bertocci, prof. Pilar Chìas Navarro.

Ceccarelli Lemut Maria Luisa (2003). Piombino. In Bianchi Giovanna (a cura di). Campiglia, un castello e il suo territorio. Firenze: All'insegna del Giglio, pp. 55-58.

Fara Amelio (1999). Leonardo a Piombino e l'ídea della città moderna tra Quattro e Cinquecento. Firenze: Olschki Editore.

Fiore Francesco Paolo (2019). Architettura e arte militare, mura e bastioni nella cultura del Rinascimento. Roma: Campisano Editore.

Heydenreich Ludwig H. (1974). I progetti di Leonardo per fortificare Piombino. In Almanacco italiano, vol. LXXV, pp. 332-339. Firenze: Giunti Editore.

Lazzarini Maria Teresa (201 I). Le chiese di Piombino. Pisa: Pacini Editore.

Marani Pietro C. (1984). L'architettura fortificata negli studi di Leonardo da Vinci. Firenze: Olschki Editore.

Pedretti Carlo (1978). Leonardo architetto. Milano: Electa.

Reti Ladislao (a cura di). (1974). Leonardo da Vinci. I Codici di Madrid. 5 voll. Firenze: Giunti Barbera.

Authors
Stefano Bertocci, Università di Firenze, stefano.bertocci@unifi.it
Matteo Bigongiari, Università di Firenze, matteo.bigongiari@unifi.it

To cite this chapter: Bertocci Stefano, Bigongiari Matteo (2020). Le fortificazioni di Piombino di Leonardo da Vinci: la riscoperta delle tracce dell'impianto rinascimentale attraverso il rilievo digitale e il disegno/The fortifications of Piombino by Leonardo da Vinci: the discovery of the traces of the Renaissance system through digital survey and drawing. In Arena A., Arena M., Brandolino R.G., Colistra D., Ginex G., Mediati D., Nucifora S., Raffa P. (a cura di). Connettere. Un disegno per annodare e tessere. Atti del $42^{\circ}$ Convegno Internazionale dei Docenti delle Discipline della Rappresentazione/Connecting. Drawing for weaving relationships. Proceedings of the 42th International Conference of Representation Disciplines Teachers. Milano: FrancoAngeli, pp. 87-102. 